\title{
Mycological Indicators in Evaluating Conservation Status: The Case of Quercus spp. Dehesas in the Middle-West of the Iberian Peninsula (Spain)
}

\author{
Prudencio García Jiménez ${ }^{1}$, Abel Fernández Ruiz ${ }^{1}$, José Sánchez Sánchez ${ }^{1,2}$ and \\ David Rodríguez de la Cruz ${ }^{1,2, *(1)}$ \\ 1 Spanish-Portuguese Agricultural Research Centre (CIALE), Universidad de Salamanca, Río Duero 12, \\ 37185 Villamayor, Spain; prudenciogarjim@gmail.com (P.G.J.); abel@usal.es (A.F.R.); jss@usal.es (J.S.S.) \\ 2 Department of Botany and Plant Physiology, Universidad de Salamanca, Licenciado Méndez Nieto s/n, \\ 37007 Salamanca, Spain \\ * Correspondence: droc@usal.es; Tel.: 0034-677-584-172
}

Received: 11 November 2020; Accepted: 11 December 2020; Published: 14 December 2020

check for updates

\begin{abstract}
The use of bioindicators to assess the conservation status of various ecosystems is becoming increasingly common, although fungi have not been widely used for this purpose. The aim was to use the analysis of the macromycetes fruiting bodies in the area of a natural reserve and the degree of preservation of its different zones combined with the use of geographical information systems (GIS). For this purpose, quantitative and qualitative fungal samples were carried out in plots of the middle-west of the Iberian Peninsula previously delimited and characterised thanks to GIS during the springs and autumns of the 2009-2012 period. In addition, the lifestyles of the fungal species were analysed as well as the influence of the main meteorological parameters on fungal fruiting. A total of 10,125 fruiting bodies belonging to 148 species were counted on 20 plots with four vegetation units (holm oak dehesas, mixed holm oaks and Pyrenean oak dehesas with different abundance and grasslands). The distribution of the different species, their lifestyles and the number of fruiting bodies in the different plots of the reserve indicated that the eastern part was best conserved, showing that the combination of fungal diversity studies and the use of GIS could be useful in the management of areas with environmental relevance.
\end{abstract}

Keywords: fungal indicators; GIS; conservation; dehesas; MW Spain

\section{Introduction}

The sustainable management of forests and resources that can be obtained through them, such as wood, fruit, or even ecosystem services $\left(\mathrm{CO}_{2}\right.$ capture), is becoming of considerable interest in recent decades $[1,2]$. One of the most important aspects that must be taken into account before dealing with the management of the forests and their resources is assessing their state of conservation. In this way, it will be possible to know the initial stage before starting any kind of action. To this end, throughout this century various methods have been proposed to evaluate the degree of preservation in various woodlands $[3,4]$, in which distinct factors are evaluated through different indices. However, these methods did not, or only very partially, consider the contribution of one of the groups of organisms with a fundamental role in forest dynamics, fungi [5]. Traditionally, three types of life forms are considered in the Fungi kingdom, symbiotic with various plant species, saprophytes decomposing material of various types and parasites on other species in various kingdoms [6]. The relevance of these organisms and their lifestyles in the dynamics of different plant formations, especially forests, is well known, favouring the recycling of products resulting from the activity of the ecosystem 
itself $[7,8]$, the growth of various tree and shrub species [9], many of which are fundamental in the physiognomic and ecological composition of the forest itself [10], and even with a potential role in the bioremediation of various pollutants [11]. It should not be overlooked that a good number of the fruiting bodies of these organisms also constitute a natural resource [12], nor the fact that $74 \%$ of threatened fungal species are found in woody formations compared to $9 \%$ present in different types of pasture [13], also highlighting the environmental importance of this type of vegetation. Most of the studies carried out on fungal fruiting bodies as indicators of the conservation status of different ecosystems were based on the occurrence of fruiting bodies of different species [14], or assessing the connectivity between tree formations and myceliums of saprophytic species in wood remains [15]. No assessments were developed through these studies, therefore, that could be transferred to technical teams managing forest areas as a further factor to be taken into account when estimating the preservation of different ecosystems.

The aim of this paper was the use of fungal sporocarps produced in a forest ecosystem as a relevant factor to assess the conservation status of these plant formations, and in the context of a characteristic habitat type of the central-western Iberian Peninsula, the dehesas (in Spanish). These ecosystems, also known as montado (in Portuguese), are the most widespread complex agrosilvopastoral systems in Europe and are dominated by several species of the genus Quercus L. [16]. It was also intended to examine the variation in the production of macroscopic fruiting bodies belonging to Ascomycota and Basidiomycota, both quantitatively (in a number of sporocarps) and qualitatively (species diversity) and the possible influence of meteorological parameters, extending the preliminary results shown in previous work within the study area [17].

\section{Materials and Methods}

\subsection{Study Area}

This work was carried out in the "Campanarios de Azaba" Natural Reserve located in the Middle-West of the Iberian Peninsula ( $40^{\circ} 29.769 \mathrm{~W} 6^{\circ} 47.551$ ). This area has an area of 522 hectares located about 800 m.a.s.l. with a Mediterranean oceanic pluviseasonal bioclimate (Rivas-Martínez et al., 2001). The dominant ecosystem in the area was an open agrosilvopastoral ecosystem present in the Iberian Peninsula called "dehesa" (in Spanish) or "montado" (in Portuguese), with a predominance of holm oak (Quercus ilex subsp. ballota (Desf.) Samp.) and Pyrenean oak (Quercus pyrenaica Willd.), coexisting with cork oak (Quercus suber L.) and gall oak (Quercus faginea Lam.) individuals. These formations covered approximately half of the area of the reserve, which has traditionally been used for livestock (cattle and pigs) and occasionally for agriculture.

\subsection{Delimitation of Vegetation Units}

A physiognomic delimitation on a 1:1.000 scale of the different plant formations present in the reserve was developed, obtaining a series of plots or tesserae, which were assigned to general vegetation units, through geographic information systems (GIS), with the ArcGIS ${ }^{\circledR} 10.1$ software package. This theoretical and practical delimitation in different plots was conducted following physiognomic and ecological criteria by means of the main plant formations and making reference mainly to the tree types $[18,19]$. The predominance of holm oak or Pyrenean oak in the mixed dehesas was established on the basis of a greater abundance of one or the other species, which was defined in at least $60 \%$ of the trees present in each vegetation unit. The characterization of the territory from an ecological point of view was completed by assigning the different vegetation units to habitats defined by the European Union $[19,20]$, for future management activities in the study area.

\subsection{Mycological Surveys}

The evaluation of macromycological diversity was carried out between autumn 2009 and spring 2012, through four visits per weather station during three autumns (years 2009, 2010 and 2011) 
and three springs (years 2010, 2011 and 2012) to collect the different fungal fruiting bodies. In total, they involved 24 samples ( 3 autumns +3 springs $\times 4$ visits per weather station) of $30 \mathrm{~m} \times 30 \mathrm{~m}$ [21] conducted on each of the previously delimited plots. The Ascomycota and Basidiomycota sporocarps were subsequently identified in the laboratory by macroscopic and microscopic character analysis using a LEICA DMRD microscope attached to a LEICA DC100 video camera and the LEICA Qwin image software. Specific literature was used on taxonomic discrimination ([22-26], among others), following CABI Index Fungorum [27] for nomenclature. The influence of meteorological parameters on fructification, both qualitative (in species diversity) and quantitative (in a number of sporocarps) was performed by means of Spearman's non-parametric correlation statistic, taking into account that fructification does not follow a normal distribution throughout the years. The software applied was SPSS v.23. The meteorological parameters used were the averages of average, maximum, minimum and difference in temperature (in ${ }^{\circ} \mathrm{C}$ ) and total rainfall for the previous seven days [28], giving a correlation coefficient with values between -1 and 1 , representing a negative and positive correlation, respectively. The meteorological data of temperature and precipitation were provided by the Spanish State Agency of Meteorology (AEMET) via the weather stations located in Navasfrías ( $20 \mathrm{~km}$ from the study area) and Alberguería de Argañán (7 km away).

\subsection{Assessment of the Conservation Status}

The evaluation of the state of conservation of the different plots was performed according to three parameters (health status, species richness and production of fruit bodies), estimated for each plot, and then as a whole, in order to delimit the degree of preservation of each one of them and of the reserve as a whole. These parameters and the scores assigned to the different categories are shown in Table 1. Within this estimate, plots of land assigned to disturbed environments, whether agricultural crops, reforestation, buildings or roads, as well as temporary ponds, have been discarded because they do not constitute an adequate environment for the development of fruiting bodies. Firstly, the health status was evaluated, considering the way of life of each of the identified specimens, estimating in each case its proximity to the proportion reported by Moreno [29], as an indicator of a good state of health of each plot (51\% saprophytes, $47 \%$ symbiotics and $2 \%$ parasites). The number of fungal species was also considered, as greater species richness leads to a better state of preservation of the various plots in a given area [30]. The number of specimens was taken into account with less weight than the two previous parameters since the number of fruiting bodies does not seem to be so important in assessing conservation [31]. The latter parameters were assessed by taking into account the respective maximum values reached in a plot, and scores were assigned on the basis of these values. The results that defined the scores in the different sections are indicated as follows. Health status: optimum (fungal symbiotic species $>40 \%$ ), Good (31-40\% symbiotic species), Favorable (21-30\% symbiotic species), Poor ( $<20 \%)$; Species richness: Very high ( $>60$ species), High (51-60 species), Medium (21-50 species), Low ( $<20$ species); Production fruit bodies: High ( $>800$ carpophores), Medium (300-800 carpophores), Low ( $<300$ carpophores).

Table 1. Criteria and scores taken into account to estimate the conservation status of the different plots present in the study area.

\begin{tabular}{cccccccc}
\hline \multicolumn{2}{c}{ Health Status } & \multicolumn{2}{c}{ Species Richness } & Production Fruit Bodies & \multicolumn{2}{c}{ Preservation Status } \\
Value & Health & Value & N species & Values & Carpophores & Value & Estimation \\
\hline 3 & Optimum & 3 & Very high & 2 & High & $8-7$ & Optimum \\
2 & Good & 2 & High & 1 & Medium & $6-5$ & Good \\
1 & Favourable & 1 & Medium & 0 & Low & $4-3$ & Suitable \\
0 & Poor & 0 & Low & & & $2-1$ & Poor \\
& & & & & 0 & Not favourable \\
\hline
\end{tabular}

$\mathrm{N}$ species: number of species. 


\section{Results and Discussion}

The GIS analysis of the study area and the field evaluation led to the identification of four main and vegetation units: holm oak dehesas (dominated by the holm oak), mixed dehesas of Pyrenean oak and holm oak (with a greater presence of Pyrenean oak accompanied by the holm oak), mixed dehesas of holm oak and Pyrenean oak (same as the previous case, but with a greater abundance of holm oaks), and grasslands of different types and composition. It should be noted that the different lakes of natural or artificial origin were not included in this generic synthesis of vegetation units, because no fruiting bodies were observed to develop in them, except in the case that they had a herbaceous component on their borders, and they were ascribed to grasslands (Table 2, Figure 1). In total, grouping all the above factors, 20 different plots in the study area were analysed. The delimitation in units revealed that almost a third (31\%) of the Natural Reserve was made up of holm oak dehesas, followed by grasslands (21\%), mixed dehesas of holm oak and Pyrenean oak (12\%) and mixed dehesas of Pyrenean oak and holm oak $(3 \%)$. The remaining plots, together with another third of the area analysed, were considered to be areas with a high degree of human intervention, such as crops and reforestation (15\%), Mediterranean temporary ponds or natural eutrophic ponds (11\%), and roads and built-up areas (7\%). The application of GIS for the conservation of forest formations has proven to be an effective tool in the sustainable management of their resources [32], as well as for the elaboration of preservation plans associated with these formations and their associated habitats [33].

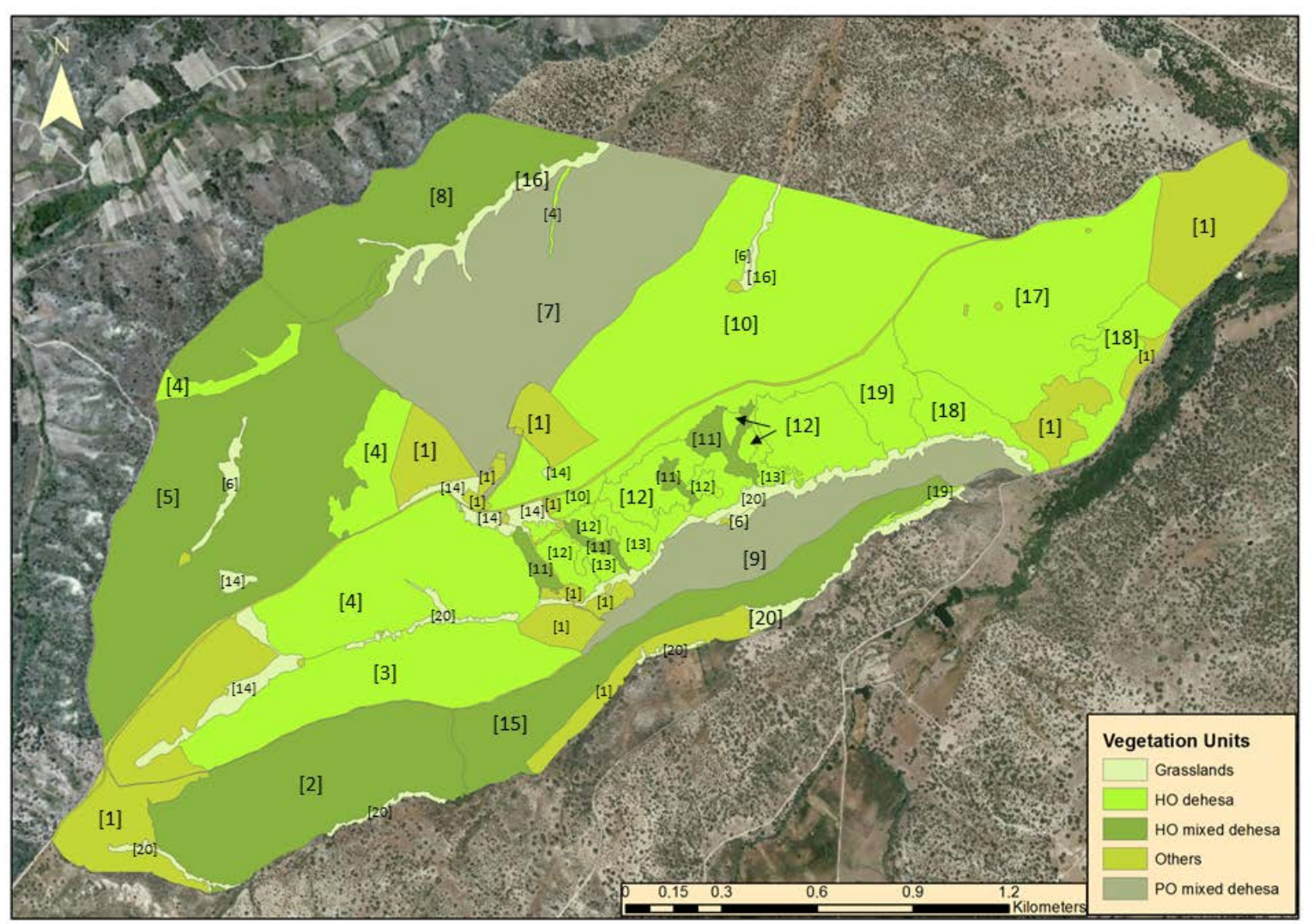

Figure 1. Vegetation units present in the "Campanarios de Azaba" Natural Reserve. HO: Holm oak; PO: Pyrenean oak. (The number of plots analysed in brackets). 
Table 2. Vegetation units described in the Natural Reserve "Campanarios de Azaba" and habitats defined by the EU (Directive 92/43 CEE) that can be placed on them, with their code (EU_Code) and whether or not they have priority status (marked with an asterisk "*” and shaded in grey).

\begin{tabular}{|c|c|c|c|}
\hline VEGETATION UNITS & EU HABITAT NAME & EU_CODE & PRIORITY \\
\hline \multirow{4}{*}{ Holm oak dehesas } & $\begin{array}{l}\text { Pseudo-steppe with grasses and } \\
\text { annuals of the }\end{array}$ & 6220 & * \\
\hline & Thero-Brachypodietea & & \\
\hline & $\begin{array}{c}\text { Endemic oro-Mediterranean } \\
\text { heaths with gorse }\end{array}$ & 4090 & $\mathrm{~Np}$ \\
\hline & $\begin{array}{c}\text { Dehesas with evergreen Quercus } \\
\text { spp. }\end{array}$ & 6310 & $\mathrm{~Np}$ \\
\hline \multirow{4}{*}{$\begin{array}{l}\text { Mixed dehesas of holm } \\
\text { oak and Pyrenean oak }\end{array}$} & $\begin{array}{c}\text { Pseudo-steppe with grasses and } \\
\text { annuals of the } \\
\text { Thero-Brachypodietea }\end{array}$ & 6220 & * \\
\hline & $\begin{array}{l}\text { Endemic oro-Mediterranean } \\
\text { heaths with gorse }\end{array}$ & 4090 & $\mathrm{~Np}$ \\
\hline & $\begin{array}{c}\text { Dehesas with evergreen Quercus } \\
\text { spp. }\end{array}$ & 6310 & $\mathrm{~Np}$ \\
\hline & $\begin{array}{c}\text { Galicio-Portuguese oak woods } \\
\text { with Quercus robur and Quercus } \\
\text { pyrenaica }\end{array}$ & 9230 & $\mathrm{~Np}$ \\
\hline \multirow{7}{*}{$\begin{array}{c}\text { Mixed dehesas of } \\
\text { Pyrenean oak and holm } \\
\text { oak }\end{array}$} & $\begin{array}{c}\text { Pseudo-steppe with grasses and } \\
\text { annuals of the } \\
\text { Thero-Brachypodietea }\end{array}$ & 6220 & * \\
\hline & $\begin{array}{l}\text { Mediterranean tall humid herb } \\
\text { grasslands of the }\end{array}$ & 6420 & $\mathrm{~Np}$ \\
\hline & Molinio-Holoschoenion. & & \\
\hline & $\begin{array}{l}\text { Endemic oro-Mediterranean } \\
\text { heaths with gorse }\end{array}$ & 4090 & $\mathrm{~Np}$ \\
\hline & $\begin{array}{c}\text { Dehesas with evergreen Quercus } \\
\text { spp. }\end{array}$ & 6310 & $\mathrm{~Np}$ \\
\hline & $\begin{array}{c}\text { Galicio-Portuguese oak woods } \\
\text { with Quercus robur and Quercus } \\
\text { pyrenaica }\end{array}$ & 9230 & $\mathrm{~Np}$ \\
\hline & $\begin{array}{l}\text { Pseudo-steppe with grasses and } \\
\text { annuals of the } \\
\text { Thero-Brachypodietea } \\
\text { Mediterranean tall humid herb } \\
\text { grasslands of the } \\
\text { Molinio-Holoschoenion. }\end{array}$ & 6420 & $\mathrm{~Np}$ \\
\hline
\end{tabular}

Np: No priority.

A total of 148 fungal species were identified in the reserve during the different visits in the period 2009-2012 (Table S1). Two species can be highlighted because they are included in the Red List of Endangered Mushrooms in Europe [34]: Hericium erinaceus (Bull.) Pers. in a mixed holm oak and Pyrenean oak dehesa, and Torrendia pulchella Bres. (=Amanita torrendi Justo) in a holm oak dehesa with sandy soil and some Pyrenean oaks [17]. The role of these red lists in conserving fungal species and the habitats in which they grow should cover more specific geographical or administrative areas, such as at country level [35]. In the Iberian Peninsula, there have been some proposals [36], but a red list has not yet been defined, and we think it would be a useful tool for the preservation of ecosystems [37]. Species richness is similar to that reported for other Mediterranean Quercus formations [38-40].

In the 2009-2010 period, almost half of the species of the whole catalogue were found, a proportion that increased to almost 70\% by the end of spring 2011 (Figure 2). In autumn 2011 almost all the species were catalogued, with only three new species appearing in spring 2012 . Seasonally, $77 \%$ of the species were collected during the autumn. This type of dynamic has already been identified in 
study plots with ecosystems similar to those in the area of analysis [41], suggesting that two years of study may be adequate to characterize fungal diversity through the analysis of fruiting bodies. However, the lack of sampling during the winter and summer could lead to a loss of information on climate change indicator species, since their sporocarps appear in adverse weather conditions [42]. The number of fruiting bodies that appeared in the set of plots analysed throughout the 24 weeks of study was 10,125, a number similar to that counted in other works also developed in Iberian dehesas [39]. The highest production of carpophores, as well as the fungal diversity, was obtained in the autumn weeks (71\% of the total), particularly autumn of 2011 where almost half of the identified fruiting bodies were counted (Figure 2). Autumn has been reported as the season with the highest fungal and spore production diversity in other works carried out in Mediterranean coastal holm-oak forests [43]. The variability in sporocarp production from one year to another is very variable [44], as our study showed, since almost twice as many fruiting bodies were counted in 2011than in the other two years combined. This variability and inter-annual species diversity seem to be linked to differences in meteorological parameters [45], mainly temperature and precipitation prior to fruiting periods [46], especially in regions with a Mediterranean climate [47]. For this reason, the influence of these two meteorological parameters on the diversity of species and the number of sporocarps was evaluated using the Spearman correlation statistic (Table 3).

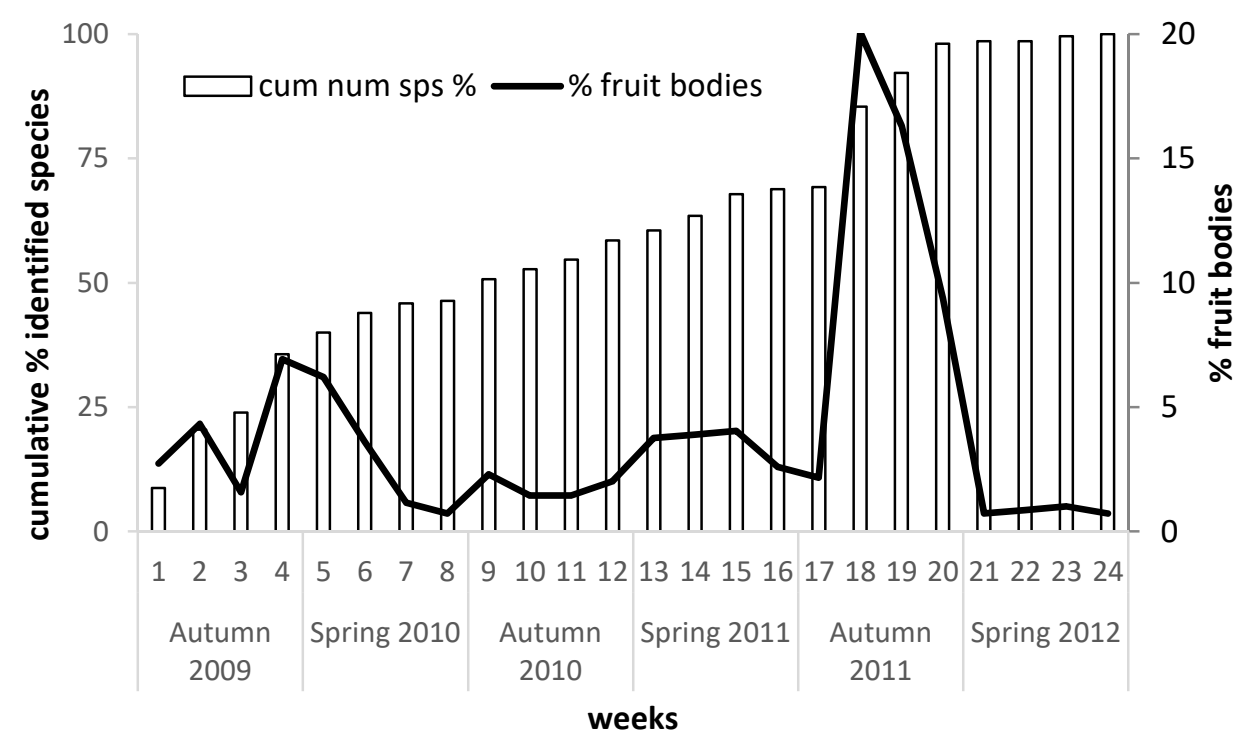

Figure 2. Number of species identified (cumulative \%) and of fruiting bodies (in \% of total) during 2009-2012.

Table 3. Influence of the average temperature and total rainfall of the previous 7 days on the diversity and production of carpophores recorded in the studied weeks.

\begin{tabular}{ccccccc}
\hline & Number sps & Tmax & Tmin & Tmean & Dif. Temp & Rainfall \\
\hline n carpophores & $\mathbf{0 . 8 4 3 7 ^ { * * }}$ & -0.2133 & 0.1926 & -0.1001 & -0.3791 & $\mathbf{0 . 4 1 3 6}^{*}$ \\
Number sps & & $-0.4502^{*}$ & -0.0063 & -0.3346 & $\underline{-0.5363 *}$ & $\mathbf{0 . 5 3 5 8}^{* *}$ \\
\hline
\end{tabular}

Number sps: number of species; Tmax: maximum daily temperature; Tmin: minimum daily temperature; Tmean: daily mean temperature; Dif. Temp: daily temperature differences; temperature in ${ }^{\circ} \mathrm{C}$. Rainfall (in $\mathrm{mm}$ ). Significance levels: ${ }^{*} 0.95 \%,{ }^{* *} 0.99 \%$. In black, significant positive correlations. Underlined, significant negative correlations.

The results indicated a significant positive correlation between the number of species and sporocarps with rainfall, which was higher in the case of the number of species. For the number of species identified there was a negative correlation with the difference in daily temperature and the maximum daily temperature in the week prior to sampling. The positive effect of previous precipitation on fungal fruiting, both quantitative and qualitative, has already been reported in Mediterranean ecosystems [48]. In these environments, the difference in previous daily temperatures and the maximum 
temperature also had a negative effect on the diversity and abundance of sporocarps [49]. However, it would be advisable to increase the number of years analysed as well as to extend the frequency of study for a better evaluation of the influence of meteorological parameters on the diversity and production of fruiting bodies [41].

The species identified were mainly distributed in $69 \%$ of holm oak dehesas, followed by mixed holm oak and Pyrenean oak dehesas, Pyrenean oak and holm oak dehesas (15\% and $12 \%$, respectively), and grasslands (4\%). One factor that could have influenced the lower location of specimens in the meadows, in addition to their smaller extension in the study area, was the previous agricultural use in some cases, which could even reduce the appearance of various fruiting bodies. In addition, the subsequent livestock load should be noted, as many of the carpophores were removed, damaged, or even ingested by the different animals for livestock use [50].

Analysis of the way of life in the area studied showed a notable predominance of saprophytic $(72 \%)$ over symbiotic $(27 \%)$ and, in a residual way, parasitic $(1 \%)$ species. Other studies carried out in Mediterranean ecosystems dominated by various species of the genus Quercus $[40,50]$ indicated lower percentages of saprophytic species, which could reflect the influence of livestock numbers on the presence of taxa with this lifestyle. This representation did not show great variations with respect to the different units of vegetation studied, with slight percentage variations in the holm oak dehesas and the mixed holm oak and Pyrenean oak in the presence of symbiotic species or otherwise in the oak grove, except in the grasslands, with a notable presence of saprophytic species (Figure 3). Centuries-old and extensive livestock use could have conditioned the large percentage of saprophytic taxa present in all the habitats considered, especially in the grasslands where livestock use was even greater, as indicated by the presence of various coprophilic species, such as the genera Coprinus Pers., Coprinopsis P. Karst., or Panaeolus (Fr.) Quél. [51].

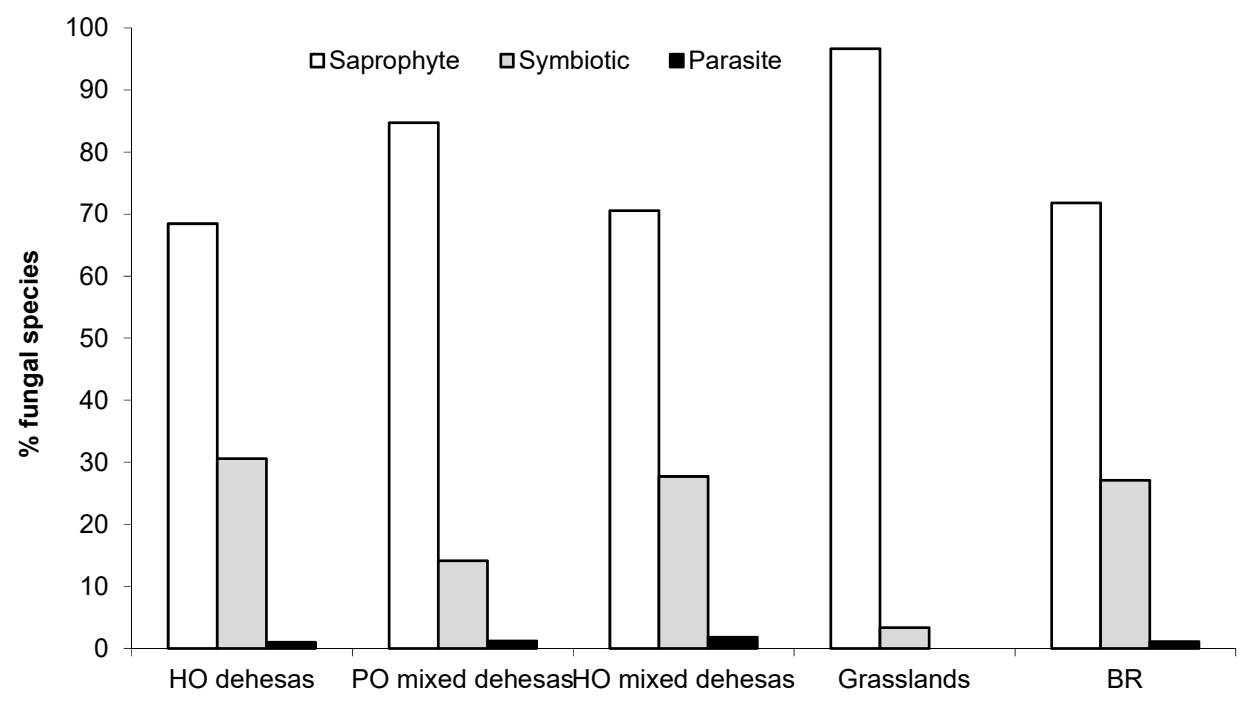

Figure 3. Average percentage representation of the different lifestyles considered in the vegetation units present within the territory under analysis (period 2009-2012). HO dehesas: holm oak dehesas. PO mixed dehesas: mixed Pyrenean oak and holm oak dehesas, dominated by the Pyrenean oak. HO mixed dehesas: mixed holm oak and Pyrenean oak dehesas, dominated by the holm oak. BR: the entire natural reserve "Campanarios de Azaba".

The evaluation of the conservation status within each of the physiognomically defined plots in the study area was based on three parameters. The results are summarized in Table 4 . The first one, the health status was estimated taking into account the way of life of each of the species and the proximity to the indicators referred to by Moreno [29]. The evaluation of this parameter made it possible to estimate that more than half of the plots in the reserve presented a good or favourable health status (59.7\% overall), although it should be noted that no plot was catalogued as "optimal" 
state (Figure 4). There could again be an influence of the livestock load in the years prior to the study on the increased presence of saprophytic taxa [52], and the low representativeness of good or optimal plots according to the lifestyle of the fungal species.

Table 4. Results of the parameters analysed to assess the state of conservation in the different plots.

\begin{tabular}{|c|c|c|c|c|c|c|}
\hline \multirow{2}{*}{ Vegetation Unit } & \multirow{2}{*}{ Plot } & \multirow{2}{*}{ N sps } & \multicolumn{3}{|c|}{ Fungal Lifestyle (\%) } & \multirow{2}{*}{ N Fruit Bodies } \\
\hline & & & Saprophte & Symbiotic & Parasite & \\
\hline \multirow[t]{2}{*}{ Culture } & 1 & NE & $\mathrm{NE}$ & NE & $\mathrm{NE}$ & $\mathrm{NE}$ \\
\hline & 6 & 16 & 59 & 41 & 0 & 240 \\
\hline \multirow{3}{*}{ Grasslands } & 14 & 6 & 100 & 0 & 0 & 90 \\
\hline & 16 & 4 & 100 & 0 & 0 & 60 \\
\hline & 20 & 11 & 91 & 9 & 0 & 165 \\
\hline \multirow{9}{*}{ HO dehesas } & 2 & 13 & 62 & 38 & 0 & 195 \\
\hline & 3 & 24 & 71 & 29 & 0 & 465 \\
\hline & 4 & 33 & 76 & 24 & 0 & 555 \\
\hline & 10 & 35 & 70 & 30 & 0 & 645 \\
\hline & 12 & 21 & 54 & 46 & 0 & 360 \\
\hline & 13 & 49 & 76 & 24 & 0 & 930 \\
\hline & 17 & 82 & 68 & 31 & 1 & 1905 \\
\hline & 18 & 56 & 51 & 46 & 3 & 1095 \\
\hline & 19 & 36 & 69 & 29 & 2 & 675 \\
\hline \multirow{4}{*}{$\begin{array}{l}\text { HO mixed } \\
\text { dehesas }\end{array}$} & 5 & 39 & 89 & 9 & 2 & 645 \\
\hline & 8 & 12 & 75 & 25 & 0 & 180 \\
\hline & 11 & 23 & 78 & 22 & 0 & 345 \\
\hline & 15 & 18 & 47 & 48 & 5 & 285 \\
\hline \multirow{2}{*}{$\begin{array}{c}\text { PO mixed } \\
\text { dehesas }\end{array}$} & 7 & 21 & 83 & 17 & 0 & 360 \\
\hline & 9 & 51 & 85 & 13 & 2 & 930 \\
\hline
\end{tabular}

$\mathrm{N}$ sps: number of species. Fungal lifestyle (\%): percentage of each type of life in relation to the total. $\mathrm{N}$ fruit bodies: number of fruit bodies. HO dehesas: Holm oak dehesas. PO mixed dehesas: mixed Pyrenean oak and Holm oak dehesas, dominated by the Pyrenean oak. HO mixed dehesas: mixed holm oak and Pyrenean oak dehesas, dominated by the holm oak. NE: not evaluated. 


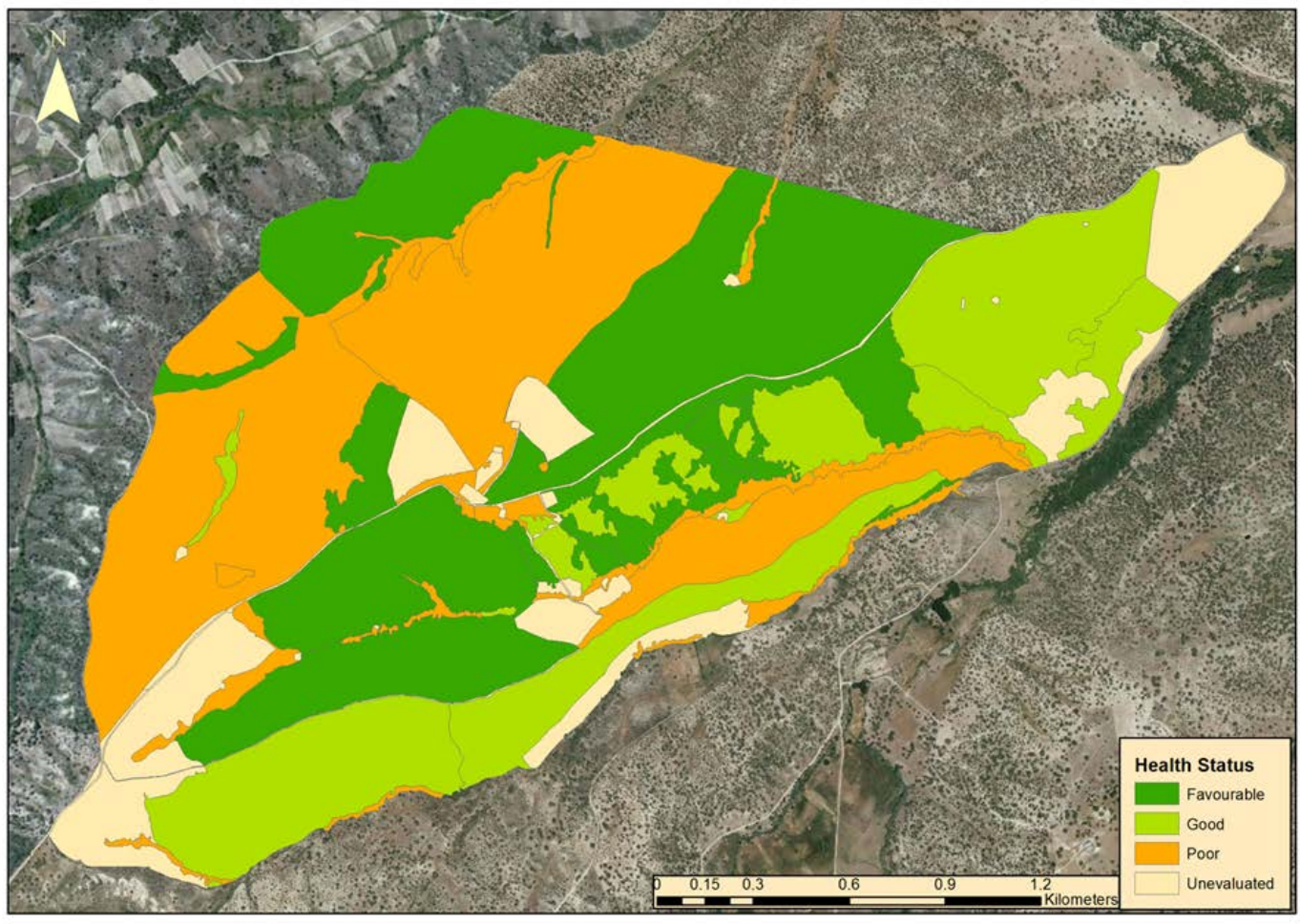

Figure 4. Health status of the different plots in the "Campanarios de Azaba" Natural Reserve according to the lifestyle in macrofungal species.

Parasite species have been found mainly in Pyrenean oak specimens, which could be due to two main and even complementary reasons. The first of these refers to the limit of distribution of the Pyrenean oak in the area, as it usually appears on north-facing slopes and/or in places with greater soil humidity [53]. The appearance of a series of years in which a decrease in the total amount of precipitation or even in its seasonal distribution is noted, could have influenced a weakening of this tree species and the appearance of parasitic organisms [54]. This negative effect could also be due, to a greater or lesser extent, to the different uses derived from the debudding of the Pyrenean oak formations, and, in particular, the exercise of excessive and/or inadequate pruning [55]. This worse level of conservation shown by the mixed Pyrenean oak and holm oak dehesas was also reflected in a lower degree of symbiotic species (14\%), which establish mycorrhizae mainly with this tree species, with respect to the holm oak dehesas (31\%) and the mixed holm oak and Pyrenean oak dehesas (28\%).

With regard to fungal diversity, based on the number of species, it was observed that only $7 \%$ of the plots had a very high or high number of species (Figure 5), with the percentage of plots with a medium amount (50.9\%) being notably higher, and even for those with a low number of species $(42.1 \%)$. The greatest diversity of taxa was found mainly in the eastern part of the reserve. The use of fungal diversity in plots of the same area to assess their state of conservation has been shown to be useful [56].

The last parameter, the number of sporocarps counted, showed that approximately half of the plots analysed $(49.1 \%$ ) had a low number of specimens, only $10.5 \%$ with an abundance of fruiting bodies, leaving the rest with a medium number (Figure 6). These results generally indicated a greater number of fungal specimens in the holm oak dehesas, mainly in the eastern part of the area studied. This parameter was mainly used in ecological succession studies after fires [57], since in mature plant formations it is not usually considered a very relevant parameter [31]. 


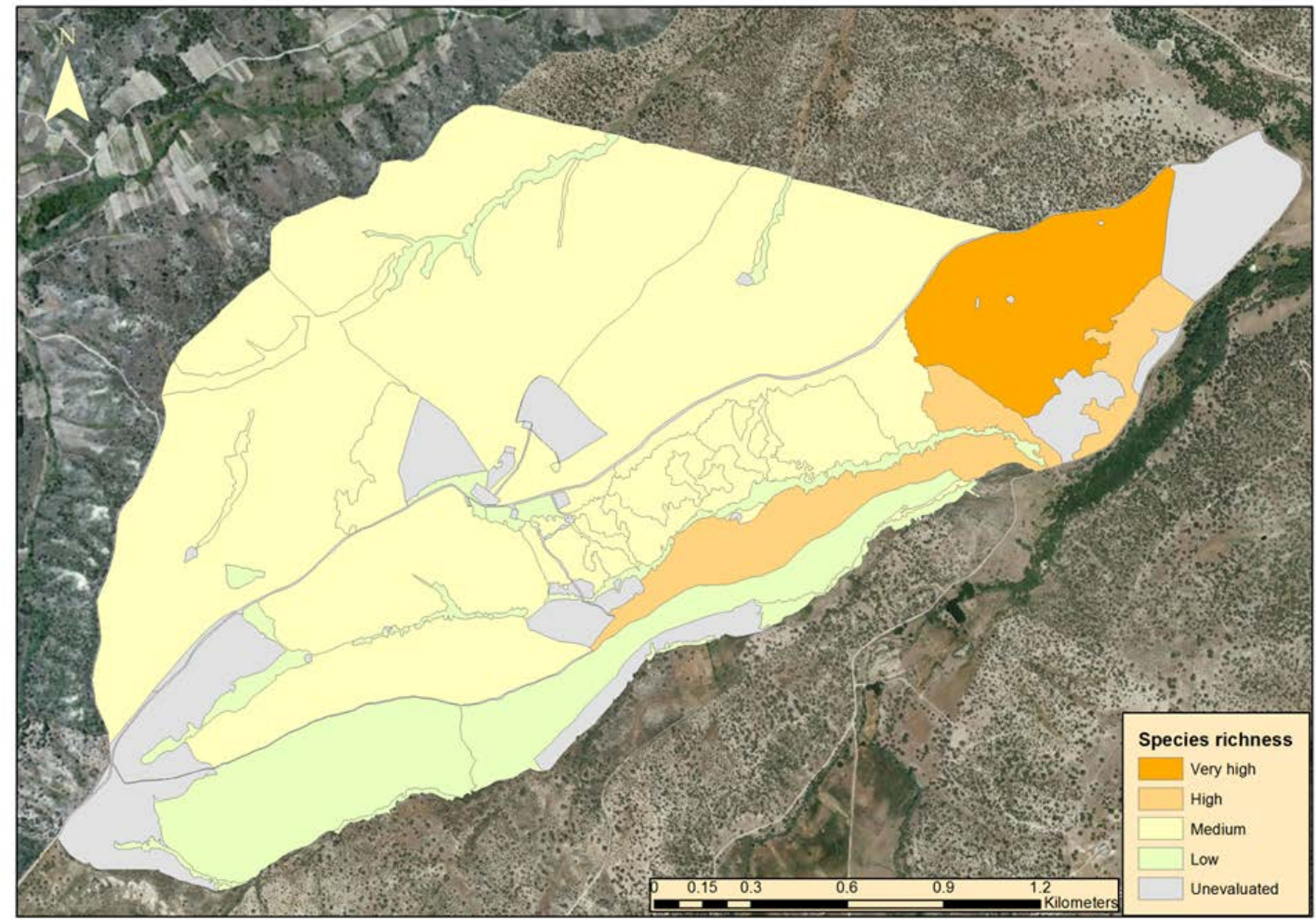

Figure 5. Number of fungal species identified in the period 2009-2012 within the different plots defined in the "Campanarios de Azaba" Natural Reserve.

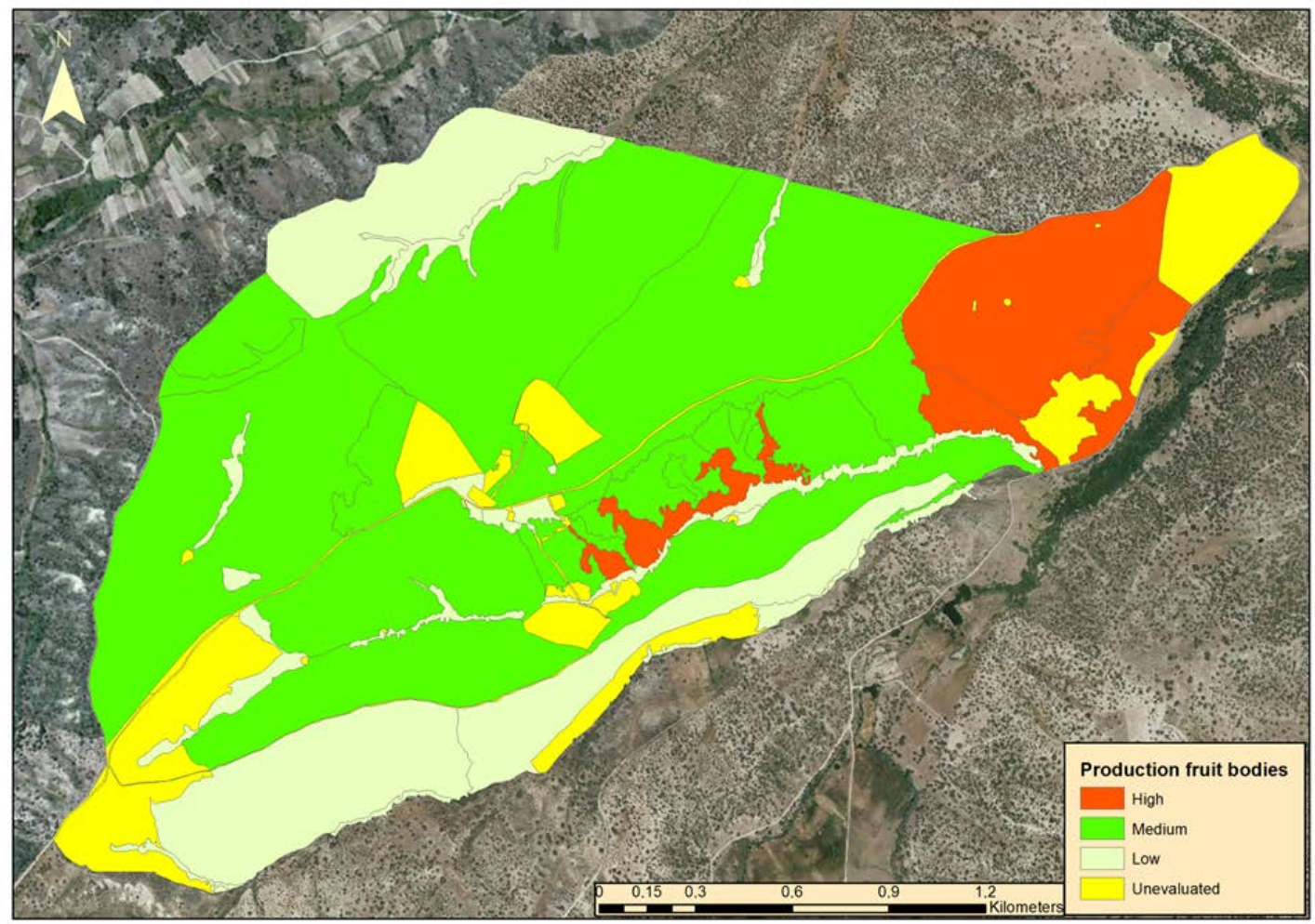

Figure 6. Number of fruit bodies found in the period 2009-2012 within the different plots defined in the "Campanarios de Azaba" Natural Reserve. 
The combination of all these parameters was used to assess the state of conservation of the various plots in the Natural Reserve (Figure 7). Using the mycological indicators, it was considered that almost a third of the plots presented a suitable state of preservation, with only a small part (5.3\%) having an optimum or good status, mainly the holm oak dehesas located at the East. Of the rest of the plots analysed, nearly half displayed poor status $(8.8 \%)$ or not favourable (38.6\%) status.

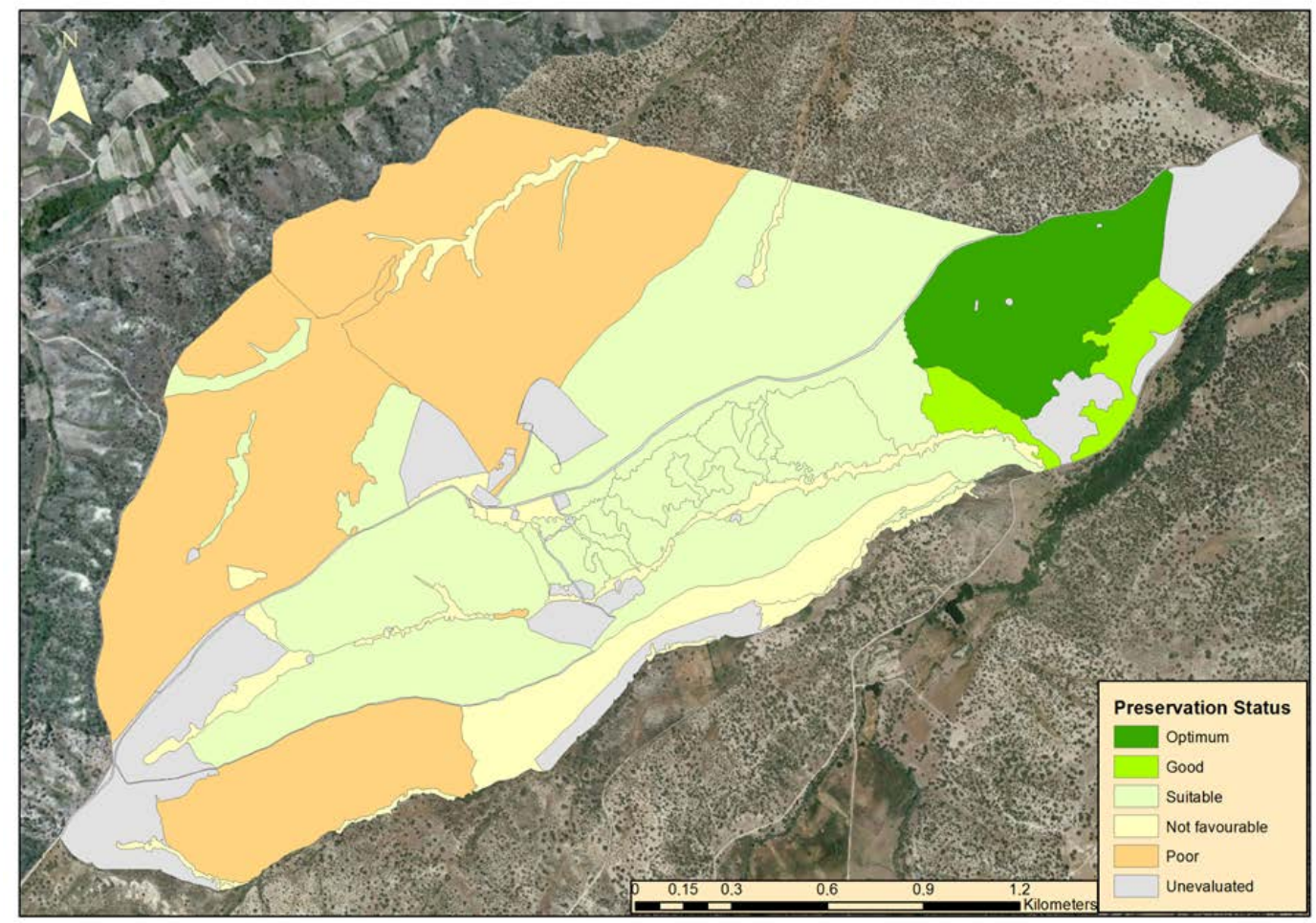

Figure 7. Preservation status of the different plots defined in the "Campanarios de Azaba" Natural Reserve according to fungal indicators (lifestyle, number of species and number of fruit bodies).

Macromycetes species have been used as indicators of the conservation status in various forest systems [58], focusing mainly on the dynamics of symbiotic species, mainly ectomycorrhizal [59] and sometimes with economic-gastronomic interest [60]. However, not enough is known about the fungal composition of forest formations to be able to use them widely as biological indicators of forest health [61]. In addition, some authors considered that joint studies with the dynamics and diversity of lichen-forming fungi [62] would be necessary for a more correct assessment of their degree of preservation, especially for forest habitats with older individuals [63]. In any case, the relevance of fungal species as a tool for assessing the health of habitats has been stressed [64], subject to further contributions that should be made in this field [65]. The use of GIS in the management of forest ecosystems has proven to be a very useful tool [66] and is now even employed in the planning of Mediterranean landscapes by linking economic and environmental perspectives [67]. However, studies combining fungal species as biological indicators and GIS were very scarce and related to the distribution of pathogenic fungal taxa [68]. This work aims to contribute to highlighting the relevance of macromycetes species as indicators of the degree of habitat conservation and the use of GIS for more efficient environmental management. In any case, a greater number of studies are needed in this area where possibly more years of study are contemplated in order to better evaluate mycological diversity and its dynamics, preferably evaluating possible changes in the distribution of species and their lifestyles.

Supplementary Materials: The following are available online at http://www.mdpi.com/2071-1050/12/24/10442/s1. Table S1. Mycological catalogue with the species identified in the period 2009-2012 (in alphabetical order). 
Author Contributions: Conceptualization, P.G.J., D.R.d.l.C. and J.S.S.; methodology, P.G.J., D.R.d.l.C. and A.F.R.; software, D.R.d.l.C. and A.F.R.; validation, P.G.J., D.R.d.l.C., A.F.R. and J.S.S.; formal analysis, P.G.J., D.R.d.l.C. and A.F.R.; investigation, P.G.J., D.R.d.l.C., A.F.R. and J.S.S.; resources, P.G.J., D.R.d.l.C. and A.F.R.; data curation, P.G.J. and A.F.R.; writing-original draft preparation, P.G.J., D.R.d.l.C. and A.F.R.; writing—review and editing, P.G.J., D.R.d.l.C., A.F.R. and J.S.S.; visualization, P.G.J., D.R.d.l.C. and A.F.R.; supervision, P.G.J., D.R.d.l.C. and J.S.S.; project administration, D.R.d.l.C. and J.S.S.; funding acquisition, D.R.d.l.C. and J.S.S. All authors have read and agreed to the published version of the manuscript.

Funding: This research received no external funding.

Acknowledgments: The authors would like to thank José Ángel Sánchez Agudo for his technical support. This research was supported by LIFE 07/E/NAT/000762.

Conflicts of Interest: The authors declare no conflict of interest.

\section{References}

1. Gratton, L.; Hone, F. Les défis de la forêt privée: La conservation, l'utilisation durable de la forêt et l'écotourisme. Téoros 2006, 25, 30-35.

2. Goldmann, K.; Schöning, I.; Buscot, F.; Wubet, Y. Forest Management Type Influences Diversity and Community Composition of Soil Fungi across Temperate Forest Ecosystems. Front. Microbiol. 2015, 6, 1300. [CrossRef] [PubMed]

3. du Bus de Warnaffe, G.; Devillez, F. Quantifier la valeur écologique des milieux pour intégrer la conservation de la nature dans l'aménagement des forêts: Une démarche multicritères. Ann. Sci. 2002, 59, 369-387. [CrossRef]

4. Sacchis Lopes, M.; Kozhikkodan Veettil, B.; Saldanha, D.L. Assessment of Small-Scale Ecosystem Conservation in the Brazilian Atlantic Forest: A Study from Rio Canoas State Park, Southern Brazil. Sustainability 2019, 11, 2948. [CrossRef]

5. Baldrian, P. Forest microbiome: Diversity, complexity and dynamics. FEMS Microbiol. Rev. 2017, 41, 109-130. [CrossRef]

6. Perotto, S.; Angelini, P.; Bianciotto, V.; Bonfante, P.; Girlanda, M.; Kull, T. Interaction of fungi with other organisms. Plant. Biosyst. 2013, 147, 208-218. [CrossRef]

7. Lonsdale, D.; Pautasso, M.; Holdenrieder, O. Wood-decaying fungi in the forest: Conservation needs and management options. Eur. J. For. Res. 2008, 127, 1-22. [CrossRef]

8. Park, J.-H.; Pavlov, I.N.; Kim, M.-J.; Park, M.S.; Oh, S.-Y.; Park, K.H.; Fong, J.J.; Lim, Y.W. Investigating Wood Decaying Fungi Diversity in Central Siberia, Russia Using ITS Sequence Analysis and Interaction with Host Trees. Sustainability 2020, 12, 2535. [CrossRef]

9. Chávez, D.; Pereira, G.; Machuca, Á. Estimulación del crecimiento en plántulas de Pinus radiata utilizando hongos ectomicorrícicos y saprobios como biofertilizantes. Bosque 2014, 35, 57-63. [CrossRef]

10. Taylor, A.F.S.; Alexander, I. The ectomycorrhizal symbiosis: Life in the real world. Mycologist 2005, 19, 102-112. [CrossRef]

11. Kurniati, E.; Arfarita, N.; Imai, T.; Higuchi, T.; Kanno, A.; Yamamoto, K.; Sekine, M. Potential bioremediation of mercury-contaminated substrate using filamentous fungi isolated from forest soil. J. Environ. Sci. 2014, 26, 1223-1231. [CrossRef]

12. Martínez-Ibarra, E.; Gómez-Martín, M.B.; Armesto-López, X.A. Climatic and Socioeconomic Aspects of Mushrooms: The Case of Spain. Sustainability 2019, 11, 1030. [CrossRef]

13. Arnolds, E.; de Vries, B. Conservation of fungi in Europe. In Fungi of Europe-Ivestigation Recording and Mapping, 1st ed.; Pegler, D.N., Boddy, L., Ing, O., Kirk, P.M., Eds.; Royal Botanic Gardens: Kew, UK, 1993; pp. 231-238.

14. Richard, F.; Moreau, P.A.; Selosse, M.A.; Gardes, M. Diversity and fruiting patterns of ectomycorrhizal and saprobic fungi in an old-growth Mediterranean forest dominated by Quercus ilex L. Can. J. Bot. 2004, 82, 1711-1729. [CrossRef]

15. Abrego, N.; Bässler, C.; Christensen, M.; Heilmann-Clausen, J. Implications of reserve size and forest connectivity for the conservation of wood-inhabiting fungi in Europe. Biol. Conserv. 2015, 191, 469-477. [CrossRef]

16. Moreno, G.; Pulido, F.J. The Functioning, Management and Persistence of Dehesas. In Agroforestry in Europe: Current Status and Future Prospects, 1st ed.; Rigueiro-Rodríguez, A., McAdam, J., Mosquera-Losada, M.R., Eds.; Springer Science + Business Media, B.V.: Amsterdam, The Netherlands, 2009; pp. 127-160. 
17. Sánchez-Martínez, C.; Benito-Peñil, D.; García de Enterría, S.; Barajas-Castro, I.; Martín-Herrero, N.; Pérez-Ruiz, C.; Sánchez-Sánchez, J.; Sánchez-Agudo, J.A.; Rodríguez-de la Cruz, D.; Galante-Patiño, E. Manual de Gestión Sostenible de Bosques Abiertos Mediterráneos; Castilla Tradicional: Valladolid, Spain, 2012; pp. 68-79.

18. Romero-Calcerrada, R.; Novillo, C.J.; Millington, J.D.A.; Gómez-Jiménez, I. GIS analysis of spatial patterns of human-caused wildfire ignition risk in the SW of Madrid (Central Spain). Landsc. Ecol. 2008, 23, 341-354. [CrossRef]

19. European Commission. Council Directive 92/43/EEC of 21 May 1992 on the conservation of natural habitats and of wild fauna and flora. Off. J. Eur. Union 1992, L 206, 7-50.

20. VV.AA. Bases Ecológicas Preliminares Para la Conservación de los Tipos de Hábitat de Interés Comunitario en España; Ministerio de Medio Ambiente, y Medio Rural y Marino: Madrid, Spain, 2009.

21. Taylor, A.F.S. Fungal diversity in ectomycorrhizal communities: Sampling effort and species detection. Plant. Soil. 2002, 244, 19-28. [CrossRef]

22. Neville, P.; Poumarat, S. Amaniteae. Fungi Europaei; Candusso: Origgio, Italy, 2004.

23. García Jiménez, P.; Pérez Gorjón, S.; Sánchez Rodríguez, J.A.; Sánchez Sánchez, J.; Valle Gutiérrez, C.J. Setas de Salamanca; Diputación de Salamanca, Naturaleza y Medio Ambiente: Salamanca, Spain, 2005.

24. Muñoz, J. Boletus s.l. Fungi Europaei; Candusso: Origgio, Italy, 2005.

25. Parra, L.A. Agaricus s.l. Fungi Europaei. Volume 1; Candusso: Origgio, Italy, 2008.

26. Parra, L.A. Agaricus s.l. Fungi Europaei. Volume 2; Candusso: Origgio, Italy, 2012.

27. CABI Index Fungorum. Available online: http://www.indexfungorum.org/names/names.asp (accessed on 1 October 2020).

28. Baptista, P.; Martins, A.; Tavares, R.M.; Lino-Neto, T. Diversity and fruiting pattern of macrofungi associated with chestnut (Castanea sativa) in the Trás-os-Montes region (Northeast Portugal). Fungal Ecol. 2010, 3, 9-19. [CrossRef]

29. Moreno, G. Setas Micorrrizógenas, Parásitas y Saprófitas; Una Forma de Valorar el Impacto Ambiental en Nuestros Bosques; Congress Communication: Laredo, Spain, 1996.

30. Saitta, A.; Anslan, S.; Bahram, M.; Brocca, L.; Tedersoo, L. Tree species identity and diversity drive fungal richness and community composition along an elevational gradient in a Mediterranean ecosystem. Mycorrhiza 2018, 28, 39-47. [CrossRef]

31. Richard, F.; Millot, S.; Gardes, M.; Selosse, M.A. Diversity and specificity of ectomycorrhizal fungi retrieved from an old-growth Mediterranean forest dominated by Quercus ilex. New Phytol. 2005, 166, 1011-1023. [CrossRef]

32. Lehtomäki, J.; Tomppo, E.; Kuokkanen, P.; Hanski, I.; Moilanen, A. Applying spatial conservation prioritization software and high-resolution GIS data to a national-scale study in forest conservation. Ecol. Manag. 2009, 258, 2439-2449. [CrossRef]

33. Hernández-Lambraño, R.E.; Rodríguez de la Cruz, D.; Sánchez-Agudo, J.A. Spatial oak decline models to inform conservation planning in the Central-Western Iberian Peninsula. Ecol. Manag 2019, 441, 115-126. [CrossRef]

34. Dahlberg, A.; Croneborg, H. 33 Threatened Fungi in Europe; Complementary and Revised Information on Candidates for Listing in Appendix I of the Bern Convention: Uppsala, Sweden, 2003.

35. Dahlberg, A.; Mueller, G.M. Applying IUCN red-listing criteria for assessing and reporting on the conservation status of fungal species. Fungal Ecol. 2011, 4, 147-162. [CrossRef]

36. Calonge, D. Apuntes para la futura Lista Roja de hongos españoles. Bol. Soc. Micol. Madr. 2004, 28, $391-395$.

37. Heilmann-Clausen, J.; Barron, E.S.; Boddy, L.; Dahlberg, A.; Griffith, G.W.; Nordén, J.; Ovaskainen, O.; Perini, C.; Senn-Irlet, B.; Halme, P. A fungal perspective on conservation biology. Conserv. Biol. 2015, 29, 61-68. [CrossRef] [PubMed]

38. Ortega, A.; Lorite, J. Macrofungi diversity in cork-oak and holm-oak forests in Andalusia (southern Spain); an efficient parameter for establishing priorities for its evaluation and conservation. Cent. Eur. J. Biol. 2007, 2, 276-296. [CrossRef]

39. Azul, A.M.; Castro, P.; Sousa, J.P.; Freitas, H. Diversity and fruiting patterns of ectomycorrhizal and saprobic fungi as indicators of land-use severity in managed woodlands dominated by Quercus suber-A case study from southern Portugal. Can. J. Res. 2009, 39, 2404-2417. [CrossRef] 
40. Fernández, A.; Sánchez, S.; García, P.; Sánchez, J. Macrofungal diversity in an isolated and fragmented Mediterranean Forest ecosystem. Plant. Biosyst. 2019, 154, 139-148. [CrossRef]

41. Fernández, A. Diversidad Macrofúngica del Monte de la Orbada (Salamanca, España), un Ecosistema Forestal Mediterráneo Aislado y Fragmentado. Ph.D. Thesis, Universidad de Salamanca, Salamanca, Spain, 2019.

42. Moreno, G.; Manjón, J.L.; Álvarez-Jiménez, J. Los hongos y el cambio climático. In Los Bosques y la Biodiversidad frente al Cambio Climático: Impactos, Vulnerabilidad y Adaptación en España; Herrero, A., Zavala, M.A., Eds.; Ministerio de Agricultura, Alimentación y Medio Ambiente: Madrid, Spain; pp. 129-135.

43. Perini, C.; Barluzzi, C.; De Dominicis, V. Seasonal fruit body production of macrofungi in Mediterranean vegetation. Bocconea 1996, 5, 359-373.

44. Boddy, L.; Büntgen, U.; Egli, S.; Gange, A.C.; Heegaard, E.; Kirk, P.M.; Mohammad, A.; Kauserud, H. Climate variation effects on fungal fruiting. Fungal Ecol. 2014, 10, 20-33. [CrossRef]

45. Andrew, C.; Heegaard, E.; Høiland, K.; Senn-Irlet, B.; Kuyper, T.W.; Krisai-Greilhuber, I.; Kirk, P.M.; Heilmann-Clausen, J.; Gange, A.C.; Egli, S.; et al. Explaining European fungal fruiting phenology with climate variability. Ecology 2018, 99, 1306-1315. [CrossRef] [PubMed]

46. Jarvis, S.G.; Holden, E.M.; Taylor, A.F.S. Rainfall and temperature effects on fruit body production by stipitate hydnoid fungi in Inverey Wood, Scotland. Fungal Ecol. 2017, 29, 137-140. [CrossRef]

47. Ágreda, T.; Águeda, B.; Olano, J.M.; Vicente-Serrano, S.M.; Fernández-Toirán, M. Increase evapotranspiration demand in a Mediterranean climate might cause a decline in fungal yields under global warming. Glob. Chang. Biol. 2015, 21, 3499-3510. [CrossRef] [PubMed]

48. Salerni, E.; Laganà, A.; Perini, C.; Loppi, S.; Dominicis, V.D. Effects of temperature and rainfall on fruiting of macrofungi in oak forests of the Mediterranean area. Isr. J. Plant Sci. 2002, 50, 189-198. [CrossRef]

49. Ágreda, T.; Águeda, B.; Fernández-Toirán, M.; Vicente-Serrano, S.M.; Òlano, J.M. Long-term monitoring reveals a highly structured interspecific variability in climatic control of sporocarp production. Agric. For. Meteorol. 2016, 223, 39-47. [CrossRef]

50. Azul, A.M.; Mendes, S.M.; Sousa, J.P.; Freitas, H. Fungal fruitbodies and soil macrofauna as indicators of land use practices on soil biodiversity in Montado. Agroforest. Syst. 2011, 82, 121-138. [CrossRef]

51. Doveri, F. Occurrence of coprophilous Agaricales in Italy, new records, and comparisons with their European and extraeuropean distribution. Mycosphere 2010, 1, 103-140.

52. Richardson, M.J. Diversity and occurrence of coprophilous fungi. Mycol. Res. 2001, 105, 387-402. [CrossRef]

53. Sánchez de Dios, R.; Benito-Garzón, M.; Sainz-Ollero, H. Present and future extension of the Iberian submediterranean territories as determined from the distribution of marcescent oaks. Plant. Ecol. 2009, 204, 189-205. [CrossRef]

54. Nieto-Quintano, P.; Caudullo, G.; de Rigo, D. Quercus pyrenaica in Europe: Distribution, habitat, usage and threats. In European Atlas of Forest Tree Species, 1st ed.; San-Miguel-Ayanz, J., de Rigo, D., Caudullo, G., Houston Durrant, T., Mauri, A., Eds.; Publ. Off. EU: Luxembourg, 2016; pp. 158-159.

55. Moreno, G.; López-Díaz, M.L. The Dehesa: The Most Extensive Agroforestry System in Europe. In Agroforestry Systems as a Technique for Sustainable Land Management, 1st ed.; Mosquera-Losada, M.R., Fernández-Lorenzo, J.L., Rigueiro-Rodríguez, A., Eds.; Unicopia: Lugo, Spain, 2009; pp. 171-183.

56. Zotti, M.; Pautasso, M. Macrofungi in Mediterranean Quercus ilex woodlands: Relations to vegetation structure, ecological gradients and higher-taxon approach. Czech. Mycol. 2013, 65, 193-218. [CrossRef]

57. Hernández-Rodríguez, M.; Oria-de-Rueda, J.A.; Martín-Pinto, P. Post-fire fungal succession in a Mediterranean ecosystem dominated by Cistus ladanifer L. Ecol. Manag 2013, 289, 48-57. [CrossRef]

58. Laganà, A.; Salerni, E.; Barluzzi, C.; Perini, C.; De Dominicis, V. Macrofungi as long-term indicators of forest health and management in central Italy. Cryptogam. Mycol. 2020, 23, 39-50.

59. Azul, A.M.; Nunes, J.; Ferreira, I.; Coelho, A.S.; Veríssimo, P.; Trovão, J.; Campos, A.; Castro, P.; Freitas, H. Valuing native ectomycorrhizal fungi as a Mediterranean forestry component for sustainable and innovative solutions. Botany 2014, 92, 161-171. [CrossRef]

60. Ágreda, T.; Cisneros, Ó.; Águeda, B.; Fernández-Toirán, L.M. Age class influence on the yield of edible fungi in a managed Mediterranean forest. Mycorrhiza 2014, 24, 143-152. [CrossRef] [PubMed]

61. Egli, S. Mycorrhizal mushroom diversity and productivity-An indicator of forest health? Ann. For. Sci. 2011, 68, 81-88. [CrossRef] 
62. Jönsson, M.T.; Ruete, A.; Kellner, O.; Gunnarsson, U.; Snäll, T. Will forest conservation areas protect functionally important diversity of fungi and lichens over time? Biodivers. Conserv. 2017, 26, 2547-2567. [CrossRef]

63. Izzo, A.; Agbowo, J.; Bruns, T.D. Detection of plot-level changes in ectomycorrhizal communities across years in an old-growth mixed-conifer forest. New Phytol. 2005, 166, 619-630. [CrossRef]

64. Berglund, H.; Jonsson, B.G. Nested plant and fungal communities; the importance of area and habitat quality in maximizing species capture in boreal old-growth forests. Biol. Conserv. 2003, 112, 319-328. [CrossRef]

65. Dahlberg, A.; Genney, D.R.; Heilmann-Clausen, J. Developing a comprehensive strategy for fungal conservation in Europe: Current status and future needs. Fungal Ecol. 2010, 3, 50-64. [CrossRef]

66. Falcão, A.O.; Borges, J.G. Designing decision support tools for Mediterranean forest ecosystems management: A case study in Portugal. Ann. Sci. 2005, 62, 751-760. [CrossRef]

67. Molina, J.R.; Rodríguez y Silva, F.; Herrera, M.A. Integrating economic landscape valuation into Mediterranean territorial planning. Environ. Sci. Policy 2016, 56, 120-128. [CrossRef]

68. Lorestani, E.Z.; Kamkar, B.; Razaci, S.E.; Teixeira da Silva, J.A. Modeling and mapping diversity of pathogenic fungi of wheat fields using geographic information systems (GIS). J. Crop Prot. 2013, 54, 74-83. [CrossRef]

Publisher's Note: MDPI stays neutral with regard to jurisdictional claims in published maps and institutional affiliations.

(C) 2020 by the authors. Licensee MDPI, Basel, Switzerland. This article is an open access article distributed under the terms and conditions of the Creative Commons Attribution (CC BY) license (http://creativecommons.org/licenses/by/4.0/). 